\title{
Reproduction of the silver John dory Zenopsis conchifer (Actinopterygii: Zeiformes) based on virgin stock condition
}

\author{
André Martins Vaz-dos-Santos ${ }^{1,4}$, Carmen Lúcia Del Bianco Rossi-Wongtschowski², \\ Renato Massaaki Honji ${ }^{3}$ \& Denis Bannwart ${ }^{2}$ \\ ${ }^{I}$ Laboratório de Esclerocronologia, Departamento de Biodiversidade, Universidade Federal do Paraná, \\ Rua Pioneiro, 2153, CEP 85950-000, Palotina, PR, Brazil. \\ ${ }^{2}$ Instituto Oceanográfico, Universidade de São Paulo, São Paulo, SP, Brazil. \\ ${ }^{3}$ Instituto de Biociências, Universidade de São Paulo, São Paulo, SP, Brazil. \\ ${ }^{4}$ Corresponding author: André Martins Vaz-dos-Santos, e-mail: andrevaz@ufpr.br
}

VAZ-DOS-SANTOS, A.M., ROSSI-WONGTSCHOWSKI, C.L.D.B., HONJI, R.M., BANNWART, D. Reproduction of the silver John dory Zenopsis conchifer (Actinopterygii: Zeiformes) based on virgin stock condition. Biota Neotropica. 14(3): e20130069. http://dx.doi.org/10.1590/1676-06032014006913

\begin{abstract}
This study describes the reproduction of the silver John dory, Zenopsis conchifer, based on data collected before its fishery exploitation in the southwestern Atlantic, Brazil, in the early 2000s. Biological material was collected through bottom-trawl surveys in 2001 and 2002 from depths of 100 to $600 \mathrm{~m}$. A total of 1,056 individuals ranging from 57 to $504 \mathrm{~mm}$ Ls were analyzed. A sex ratio analysis showed that males were predominant among the shorter fishes $(<240 \mathrm{~mm} \mathrm{Ls})$ and females among the longer ones (> $320 \mathrm{~mm} \mathrm{Ls}$ ). Between $240 \mathrm{~mm}$ and $319 \mathrm{~mm}$ Ls sex-ratio was 1:1. The silver John dory is a multiple spawner. Spawning is protracted and more intensive during August and November, when both females and males in spawning capable actively spawning and in regression/regeneration stages were predominant. In this period average values of gonadosomatic index were also higher. For both sexes, the first maturation occurs at $220 \mathrm{~mm} \mathrm{Ls}$ and at $240 \mathrm{~mm}$ Ls all fish can be considered adult. The recruitment apparently takes place from February to May. The length-weight relationships fitted to all specimens and for both sexes yielded $b$ coefficients of $\sim 2.7$. The virgin stock of $Z$. conchifer here characterized, may serve a basis for future studies on the effects of fisheries on the reproduction of the species.
\end{abstract}

Keywords: spawning period and area, length at first maturation, sex ratio, gonadosomatic index.

VAZ-DOS-SANTOS, A.M., ROSSI-WONGTSCHOWSKI, C.L.D.B., HONJI, R.M., BANNWART, D. Reprodução do peixe galo-de-profundidade Zenopsis conchifer (Actinopterygii, Zeiformes) baseada em um estoque virgem. Biota Neotropica. 14(3): e20130069. http://dx.doi.org/10.1590/1676-06032014006913

Resumo: O presente estudo descreve a reprodução do peixe galo-de-profundidade, Zenopsis conchifer, a partir de dados pretéritos a sua explotação pesqueira no Atlântico Sudoeste, Brasil, iniciada nos anos 2000. As coletas foram realizadas durante cruzeiros de prospecção pesqueira com arrasto-de-fundo em 2001 e 2002, em profundidades entre 100 e 600 m. Um total de 1056 exemplares (comprimento padrão entre $57 \mathrm{~mm}$ e $504 \mathrm{~mm}$ ) foi examinado. A proporção sexual mostrou que machos predominam em comprimentos inferiores a $240 \mathrm{~mm}$, que entre $240 \mathrm{~mm}$ e $319 \mathrm{~mm}$ a proporção é de 1:1 e que fêmeas predominam a partir de $320 \mathrm{~mm}$. O peixe galo-de-profundidade apresenta desova múltipla, mais intensa entre agosto e novembro, quando predominam fêmeas e machos desovantes ativos e em regressão/ regeneração. Neste período foram registrados os maiores valores do índice gonadossomático. Para ambos os sexos a primeira maturação se dá aos $220 \mathrm{~mm}$ de comprimento padrão e com $240 \mathrm{~mm}$ os indivíduos são considerados adultos. O recrutamento de jovens para o estoque adulto foi mais intenso entre fevereiro e maio. Os valores dos coeficientes $b$ das relações comprimento peso ajustadas para todos os peixes e por sexo ficaram em torno de 2,7. As condições do estoque virgem de $Z$. conchifer aqui caracterizadas podem servir como um referencial para futuros estudos sobre os efeitos da pesca na reprodução da espécie.

Palavras-chave: época e área de desova, comprimento de primeira maturação, proporção sexual, índice gonadossomático. 


\section{Introduction}

The silver John dory, Zenopsis conchifer (Lowe 1852) (Zeiformes: Zeidae), is a benthopelagic species found in the Indian and Atlantic Oceans. In the Atlantic, this species occurs along the east coast of the Americas from Nova Scotia, Canada to Tierra del Fuego, Argentina (Froese \& Pauly 2013). This zeid fish is found along the Brazilian coast (Menezes et al. 2003), with higher biomass (almost 14,000 tons) occurring on the continental shelf and slope of southeastern and southern Brazil (21-34 $\left.{ }^{\circ} \mathrm{S}\right)$ (Haimovici et al. 2008).

The first published data on the silver John dory fishery dates back to the 1990s, when FAO statistics detailed the catches of the United States and Portugal fleets (Sibeni \& Calderini 2012). Between 2001 and 2010, the average annual Portuguese catch reached 26 tons, whereas the American catches averaged 46 tons. In Brazil, the species became a target of the trawl fleet in 2001, and the catches reached a peak of 147 tons in 2003 (Perez \& Wahrlich 2005, Valentini \& Pezzutto 2006). After this increase, the landings decreased steadily to 17 tons in 2008 (UNIVALI/CTTMar 2009), increasing again and remaining at approximately 40 tons in 2009 and 2010 (UNIVALI/CTTMar 2011). In the bottom trawl surveys conducted during the Brazilian Program for the Assessment of the Exclusive Economic Zone (REVIZEE Program, 19962006) (BRASIL 2006), Z. conchifer represented the secondranked species in terms of weight and was considered a potential resource (Haimovici et al. 2008).

Despite the commercial importance of the silver John dory, almost all previous studies of this species biology were restricted to its distribution and occurrence (Froese \& Pauly 2013). Its life cycle and habitats in the northeastern Atlantic were analyzed (Zidowitz \& Fock 2004, Fock \& Zidowitz 2004). In Brazilian waters, the silver John dory was studied in terms of distribution and occurrence (Vazzoler \& Iwai 1971, Figueiredo \& Menezes 1980) fishery potential (Yesaki et al. 1976, Haimovici et al. 1994, Perez 2006), larval development (Weiss et al. 1987), diet (Muto et al., 2005) gonad maturation (Vazdos-Santos 2009) and biological aspects based on harvesting (Martins \& Schwingel 2012). The ecological importance of the silver John dory deserves attention. It is a predator on fishes and feeds primarily in pelagic environments and it is consumed by important species as Trichiurus lepturus (Muto et al. 2005) and Thunnus albacares (Vaske \& Castello 1998). Its ecological strategy resembles that of other species of fishery importance, such as M. hubbsi and other demersal fishes (Gasalla et al. 2007). Changes in the species composition of the ecosystem of Southeastern-Southern Brazil due to fisheries pressure enhanced Z. conchifer landings (Perez et al. 2003, Perez 2006, Kolling et al. 2008).

Zenopsis conchifer occurs mainly in the upper slope and secondly at the shelf break and although it makes vertical migrations in the water column to feed on pelagic items (Muto et al. 2005), it is strongly associated with the bottom. Few small specimens were documented $(\mathrm{n}=64$; lengths $16-185 \mathrm{~mm} \mathrm{Lt})$ in the water column based on collections with midwater trawls between depths of 50 and $400 \mathrm{~m}$ (Figueiredo et al. 2002), whereas a larger number of fish was caught in bottom trawls ( $=14,503$; 30-974 mm Lt) (Bernardes et al. 2005, Haimovici et al. 2008). The industrial fleet also uses bottom trawls (Perez \& Warhlich 2005, Valentini \& Pezzutto 2006, Perez \& Pezzutto 2006).
An understanding of reproduction is fundamental to a better understanding of the long-term persistence and stability of a given stock (Moyle \& Cech 2004, Fonteles-Filho 2011). Quinn II \& Deriso (1999) emphasize the importance of knowledge on the reproductive processes of a species and the applications of this information to stock assessment and biomass estimation. The reproduction process analysis allows for a better understanding of the reproductive strategy of a species, allowing the identification of spawning areas/periods and the estimation of the length at first maturation (Wootton 1998). Several techniques are used in fish reproduction studies (Vazzoler 1996) to improve the understanding of the effect of fishing (and others) on the abundance of the species (Núñez \& Duponchelle 2009). This information facilitates the implementation of management measures, such as the determination of fishing exclusion areas, minimum sizes of capture, temporal restrictions, biomass and catchability (Vincent \& Sadovy 1998).

Despite the increasing importance of $Z$. conchifer as a fishery resource off southern Brazil, information about the species in the Atlantic Ocean is scarce. Haimovici et al. (2008) first pointed out that the reproductive cycle of the species in the southwestern Atlantic involves continuous maturation and spawning over the entire year. In order to understand the reproductive biology of $Z$. conchifer, this study aims to analyze the reproduction of the species (sex ratio, length-weight relationship, recruitment, spawning period and area, and length at first maturity) off southeastern Brazil.

\section{Materials and methods}

\section{Study area}

The study area comprises the region between Cabo Frio $\left(23^{\circ} \mathrm{S}\right)$, Rio de Janeiro State, and Cabo de Santa Marta Grande $\left(28^{\circ} 40^{\prime} \mathrm{S}\right)$, Santa Catarina State, at depths between 100 and 600 , $\mathrm{m}$ from the edge of the continental shelf to the upper slope (Figure 1). Three water masses are present in the area and at these depths. Tropical Water (TW), with temperatures above

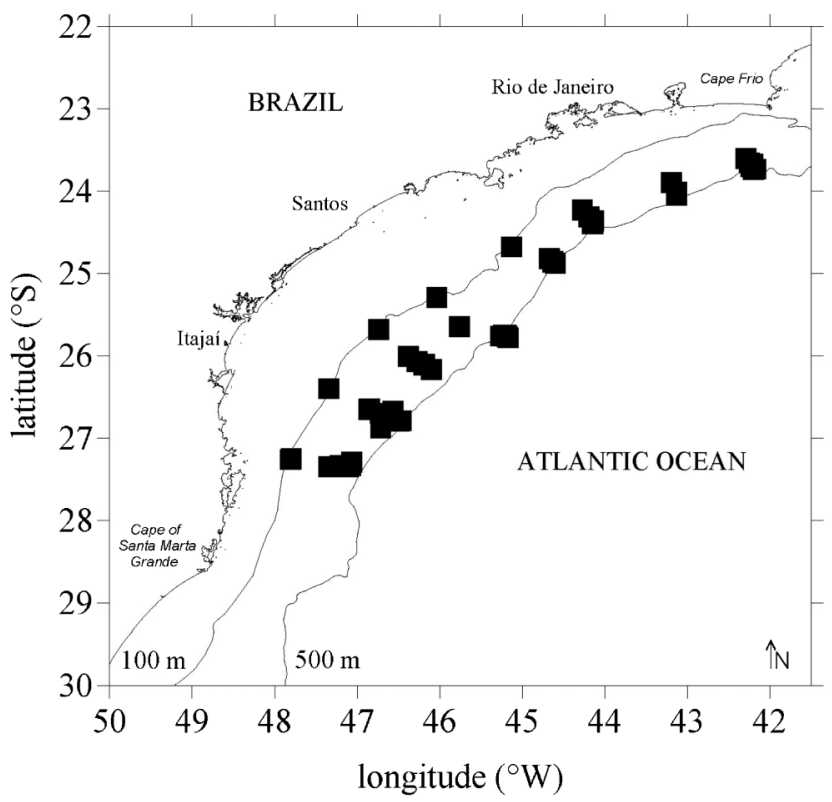

Figure 1. Capture locations for Zenopsis conchifer after bottom-trawl surveys conducted in 2001-2002. 
$20^{\circ} \mathrm{C}$, salinity exceeding 36.4 and chlorophyll-a concentrations between $0.05-0.37 \mu \mathrm{g} .1^{-1}$ is found from the surface to depths of approximately $200 \mathrm{~m}$. South Atlantic Central Water (SACW), with temperatures between $6-20^{\circ} \mathrm{C}$, salinity between $34-36.4$ and $0.10-2.77 \mu \mathrm{g} . \mathrm{l}^{-1}$ of chlorophyll-a is found between $200-500$ m (Silveira et al. 2000, Castro et al. 2006, Gaeta \& Brandini 2006). Antarctic Intermediate Water (AIW), with temperatures between $3-6^{\circ} \mathrm{C}$ and salinity between 34.2 and 34.6 , is found below $500 \mathrm{~m}$ (Castro et al. 2006). Sandy sediments are predominant on the continental shelf, and muddy sediments are found from the shelf break to the continental slope (Figueiredo \& Madureira 2004). In terms of harvesting, the Southeastern-Southern of Brazil is the most productive area of the coast, sustaining annual catches between 200,000-300,000 tons (BRASIL 2006, Valentini \& Pezzutto 2006, MPA 2011). Pelagic and demersal species have been targeted by the commercial fleet, emphasizing the growing importance that deep-sea species, such as $Z$. conchifer, have acquired from the 2000s on (Perez et al. 2009, UNIVALI/CTTMar 2011)

\section{Data source and analysis}

Samples were collected through bottom-trawl surveys conducted aboard the R/V Soloncy Moura (CEPSUL/ IBAMA) in connection with the REVIZEE Program. The area between $23^{\circ} \mathrm{S}$ and $28^{\circ} 40^{\prime} \mathrm{S}$ was sampled in 2001 and 2002 (except in December/January) at depths ranging from 100 to $600 \mathrm{~m}$ (Figure 1). Descriptions of the fishing gear and catch operations appear in Bernardes et al. (2005), and details of the bottom trawl nets appear in Haimovici et al. (2008). The total catch included 14,000 specimens of $Z$. conchifer (Haimovici et al. 2008). A subsample of 1,056 fish was retained for biological studies.

Fish standard lengths (Ls, in millimeters), total body weight (Wt, in grams) and gonad weight (Wg, g) were obtained. Sex identification and gonadal maturation was accurately identified by Vaz-dos-Santos (2009) and, for the purposes of this study, the revision and updates on the theme of Núñez \& Duponchelle (2009) and Brown-Peterson et al. (2011) were taken into consideration. Young fish showing incipient gonad development were recorded as not identified (NI). Z. conchifer presents asynchronous oocyte development and multiple spawning. Based on histological analysis, the female maturation data available included: immature (A), developing (B), spawning capable early development (C), spawning capable actively spawning (D) and regressing/ regeneration (R) (Table 1). For the male samples, data available of gonad maturation was based on stereomicroscopic analysis and individuals were considered immature (A), developing (B), spawning capable (C) and regressing/regenerating (R) (Table 1).

The Z. conchifer length-frequency data $(20 \mathrm{~mm} \mathrm{Ls})$ was examined in relation to depth strata of $100 \mathrm{~m}$ intervals. The standard lengths of the males, the females and the NI specimens were analyzed bimonthly due to the aforementioned lack of samples in the months of December and January. The sex ratio was obtained bimonthly and by standard length classes. Deviations from the expected 1:1 sex ratio were analyzed with a chi-square test (Zar 2010).

The length-weight relationships were estimated according to the standard potential model $\mathrm{Wt}=a \cdot \mathrm{Ls}^{b}$ (Huxley 1993) for all

Table 1. Zenopsis conchifer: gonadal maturation stages for females (histological analysis) and males (macroscopic analysis).

\begin{tabular}{ll}
\hline Stage & Description \\
\hline
\end{tabular}

\section{Females}

Immature (A) (never

spawned)

Developing (B)

Spawning Capable Early Development (C)

Spawning Capable Actively Spawning (D)

Regressing / Regenerating (R)

\footnotetext{
Males

Immature (A) (never spawned)

Developing (B)

Spawning Capable (C) Regressing / Regenerating (R)
}

Ovaries with predominance of perinucleolar oocytes and some cortical alveolar cells in the ovigeran lamellae.

Maturation starts and various types of cells were present in the ovaries: perinucleolar oocytes, oocytes with cortical alveoli, with initial vitellogenesis and with complete vitellogenesis. Oocytes with cortical alveoli predominate followed by initial vitellogenesis; the others were present in low frequencies.

Oocytes with initial and complete vitellogenesis cells predominate, although perinucleolar oocytes and some with cortical alveoli are present. Two situations were identified: (i) ovaries showing initial maturation in which most of the oocytes were in initial vitellogenesis, followed by oocytes with complete vitellogenesis; (ii) mature ovaries with predominance of oocytes with complete vitellogenesis and some undergoing hydration.

Hydrated oocytes predominate followed by oocytes with complete vitellogenesis; many ovaries contained post-ovulatory follicles as a consequence of recent spawning. Oocytes in the other phases were also observed in low frequencies.

Oocytes in all phases were present but perinucleolar and oocytes with cortical alveoli predominated, as in the immature ovarian, but differing from it by the presence of some oocytes with completed vitellogenesis, hydrated oocytes and post-ovulatory follicles.

Testicles were thin and cylindrical, occupying little portions of the coelom cavity, internally translucent yellowish/albescent.

Maturation starts and testicles were larger and triangular (sectioned), whitish and firm, with a milky aspect.

Testicles were large and developed, with various lobules, white.

Testicles still remain large, but presenting diverse degrees of flaccidity, sometimes almost empties. In some cases, regeneration leading to developing stage was observed. 
the fish and for the males and females separately using the iterative least squares method. A covariance analysis was used to compare the regressions between sexes. The $b$ coefficients of the model were compared with a standard value of 3 to assess isometry. The statistical procedures adopted were based on Sokal \& Rohlf (1995) and Zar (2010). A 95\% confidence level was applied to all statistical procedures.

The reproductive cycle of $Z$. conchifer was characterized based on the frequency of gonadal maturation stages analyzed (i) per period (bimonthly) and (ii) per area (degree of latitude) (Fonteles-Filho 2011). In both analyses, the frequencies were compared with a Kolmogorov-Smirnov test (Zar 2010). For the females, once that staging was based on histological analysis, we used the reproductive phases available. For the males, once that staging was based on stereomicroscopic analysis, we classified the fish as young (immature) or adult ( $\mathrm{B}+\mathrm{C}+\mathrm{R}$ stages together). In addition, the average gonadosomatic index values $(\mathrm{GSI}=\mathrm{Wg} / \mathrm{Wt} \times 100)$ (Wootton 1998) were calculated for the sexes separately, using only adults (excluding immature and young fish with unidentified sex) and then compared with a two-way ANOVA (period and area) for the females and a one-way ANOVA (period) for the males. The ANOVA was followed by a Tukey test (Zar 2010).

The average length $\left(\mathrm{L}_{50}\right)$ at first maturity and the length at which $100 \%$ fish reach the maturity $\left(\mathrm{L}_{100}\right)$ were calculated by adjusting a logistic curve (King 2007) using the iterative least squares method to adult length frequencies grouped by $20 \mathrm{~mm}$ length classes for females and males. The immature ones were considered young while the other stages of maturation were considered adults. The formulae used was: $\left.\left.\mathrm{Pi}=1 /\left\{1+\mathrm{e}^{[-r(\mathrm{Li}-\mathrm{L}} 50\right)\right]\right\}$ where $\mathrm{Pi}$ is the proportion of adults at length class $\mathrm{Li}, r$ is the slope of the curve and $\mathrm{Li}$ is the inferior limit of length class (King 2007).

In order to allow comparisons among the present results with other ones, the relationship Lt $=2.094+1.214 \mathrm{Ls}\left(\mathrm{r}^{2}=\right.$ 0.995 ; $57-504 \mathrm{~mm} \mathrm{Ls}$ ) can be used to convert lengths (Vaz-dosSantos 2009).

\section{Results}

A total of 1,056 individuals of $Z$. conchifer, with standard lengths ranging from 57 to $504 \mathrm{~mm} \mathrm{Ls} \mathrm{(mean} \mathrm{value} \mathrm{and}$ standard deviation $228.27 \pm 116.14 \mathrm{~mm} \mathrm{Ls}$ ), were sampled. The silver John dory was collected primarily on the upper slope, occupying depths from $200 \mathrm{~m}$ until $600 \mathrm{~m}$. Young and smaller fish $(<200 \mathrm{~mm} \mathrm{Ls})$ were common from inshore to the $200 \mathrm{~m}$ isobath (mostly around the $100 \mathrm{~m}$ strata). The silver John dory became rare at depths greater than $500 \mathrm{~m}$, where only one fish was captured (it was not plotted) (Figure 2). A total of 136 specimens comprised young fish with unidentified sex (these specimens were considered immature $)\left(\mathrm{Ls}_{\text {average }}=85.88 \mathrm{~mm}\right)$; 425 specimens were male $\left(\mathrm{Ls}_{\text {average }}=212.17 \mathrm{~mm}\right)$ and 495 female $\left(\mathrm{Ls}_{\text {average }}=282.50 \mathrm{~mm}\right)$. Young fish with unidentified sex were collected mainly between February and May $(n=131)$ and only five specimens in August/September. Males and females were collected during all samplings, except in December/January, due to the absence of sampling (Figure 3).

The sex ratio analysis by length classes showed that: males were predominant $(2: 1)$ at small lengths $(<240 \mathrm{~mm} \mathrm{Ls})$; females were predominant $(2: 1)$ at lengths greater than $320 \mathrm{~mm}$ Ls and; equal proportions of both sexes occurred between 240 $\mathrm{mm}$ and $319 \mathrm{~mm}$ Ls $\left(\chi^{2}=110.42, \mathrm{P}<0.001\right)$. Females predominated over the year $\left(\chi^{2}=38.40, \mathrm{P}<0.001\right)$ except in February/March. From February through May, young fish (immatures) were abundant (Figure 3).

The length-weight relationships were $\mathrm{Wt}=1.12 \times 10^{-4}$ Ls ${ }^{2.702}\left(\mathrm{r}^{2}=0.992 ; \mathrm{n}=1,056\right)$ for all fish, $\mathrm{Wt}=1.31 \times 10^{-4}$ $\mathrm{Ls}^{2.678}\left(\mathrm{r}^{2}=0.987 ; \mathrm{n}=495\right)$ for females and $\mathrm{Wt}=1.29 \times 10^{-4}$ Ls ${ }^{2.673}\left(\mathrm{r}^{2}=0.991 ; \mathrm{n}=425\right)$ for males. The slope of the regression showed negative allometry in all cases $(\mathrm{P}<0.001)$. There were significant differences between models of females and males $(\mathrm{F}=0.034, \mathrm{P}=0.854$ for coefficient $b$ and $\mathrm{F}=$ 17.459, $\mathrm{P}<0.001$ for coefficient $a$ ).

Fish at different stages of maturation were collected during all months (Figure 4). Females and males predominated in the samples between August and November when spawning was

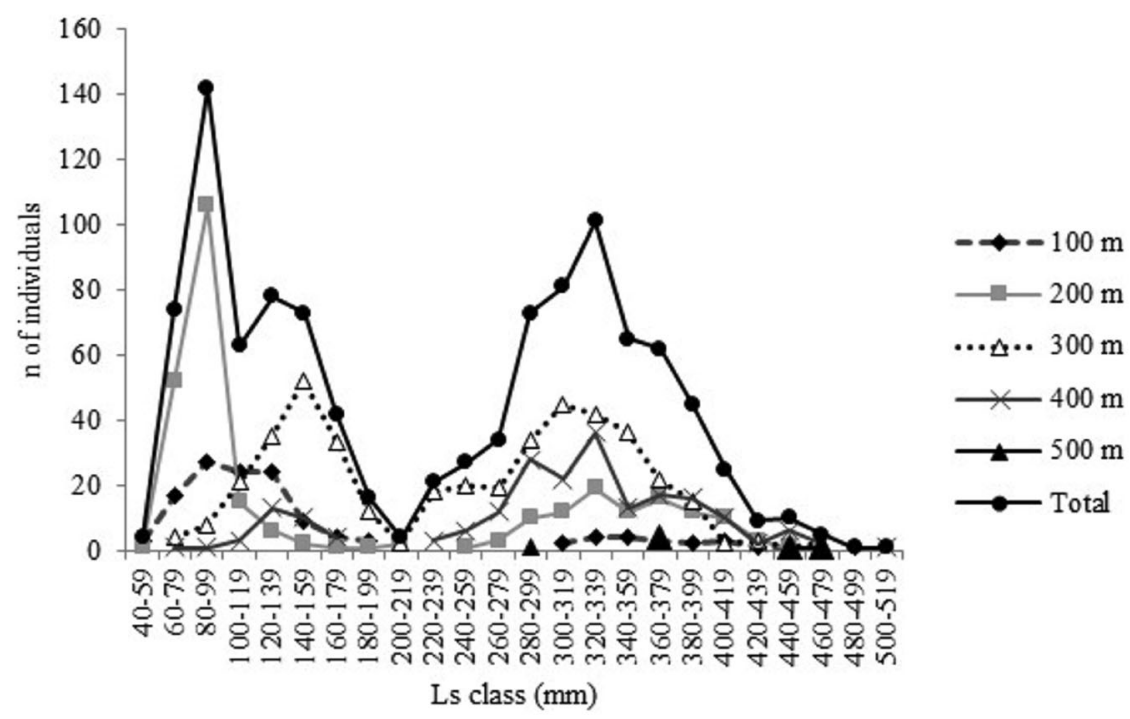

Figure 2. Zenospsis conchifer: length frequency distribution by depth of fish sampled for biological studies $(\mathrm{n}=1,056)$. 

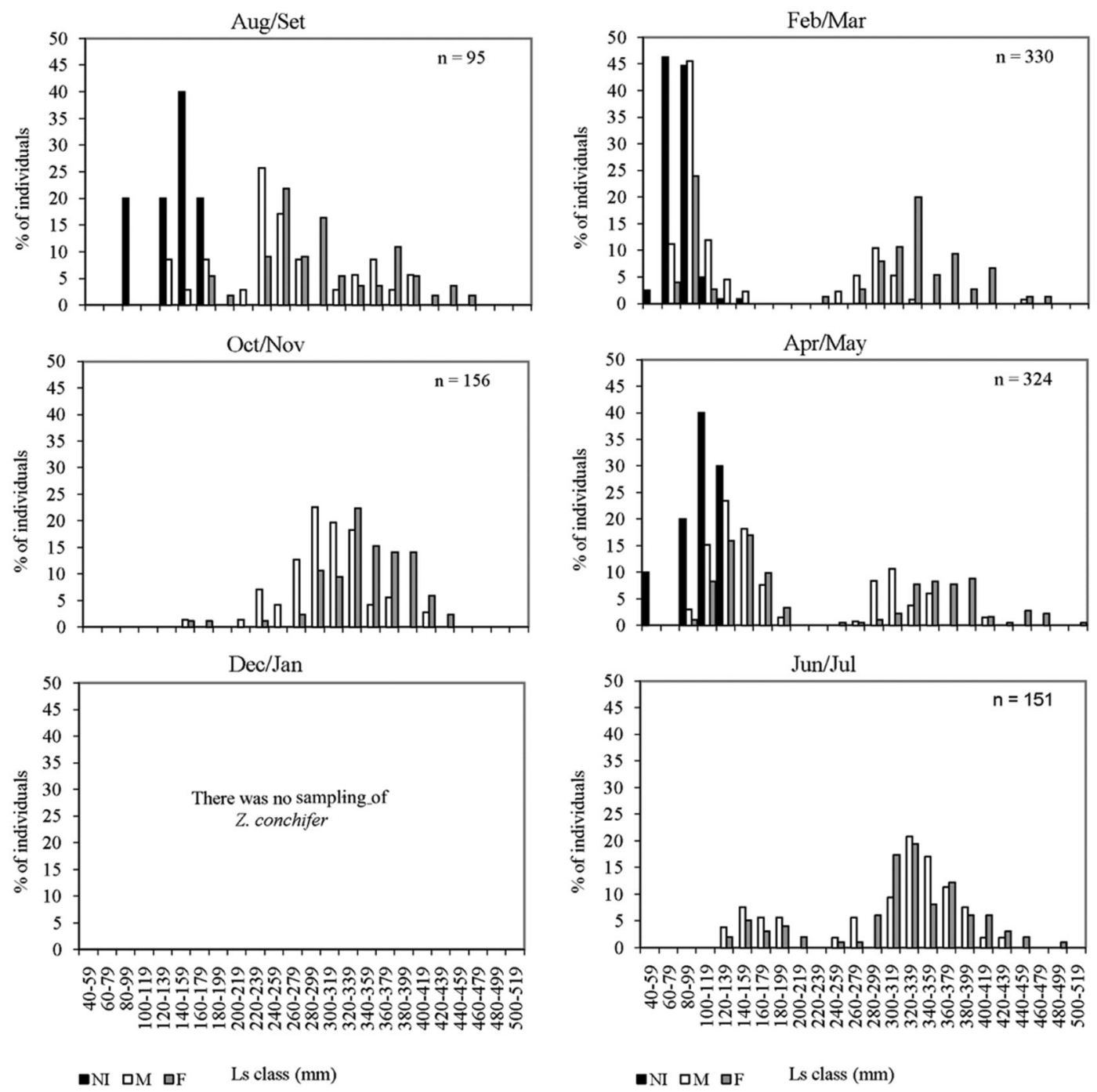

Figure 3. Zenopsis conchifer: bimonthly frequencies distribution of fishes by standard length classes by sex (NI - not identified; M - males; F females).

more intensive. During that period high frequencies of spawning capable actively spawning (D) and regressing/ regeneration (R) females (together) were observed (Figure 4a). A significant increase in their proportion was also observed in August/September and October/November (Table 2). High frequencies of adult males, dominating the samples, were also recorded (Figure 4b). Between February and July, the presence of fish of unidentified sex (younglings) (Figure 3) and immature females and males in larger proportions (Figure 4) indicates that recruitment occurs during this period. The increase of immature females in April/May (Figure $4 \mathrm{a}$ ) and the decrease in the proportion of immature males in June/July (Figure 4b) were significant (P-value $<0.05$, Table 2).

Both young (immature) and adult (in all maturation stages) females and males were found at all latitudes (Figure 5), suggesting that spawning does not occur at one specific site. Immature females and males were highly abundant at $25^{\circ} \mathrm{S}$, and immature males also occurred at $27^{\circ} \mathrm{S}$ (Table 3).

The GSI ranged between $0.1 \%$ and $14.3 \%$ of the Wt in females ( $5 \%$ on average) and between $0.04 \%$ and $6.9 \%$ of the $\mathrm{Wt}$ in males $(0.5 \%$ on average). Females and males had a similar pattern of GSI variation (Fig. 6). For both sexes, GSI was higher in the second half of the year (June/July for females and October/November for males). The lowest GSI values were found between February and May (during the first half of the year) for females. For males, lowest values extended until August/September. The ANOVA of the female mean GSI values showed an interaction between area and period $(\mathrm{F}=$ 12.47, $\mathrm{P}<0.001)$. The corresponding ANOVA for males showed only an effect of period $(\mathrm{F}=4.38, \mathrm{P}<0.001)$.

The length at first maturity for both females and males was $\mathrm{L}_{50}=220.00 \mathrm{~mm}$ Ls (slope value of $r=0.5$ ). The values of $\mathrm{L}_{100}$ $=240.00 \mathrm{~mm}$ Ls, for males and females. The bimodal frequency distributions showed a clear division between the modal values of young adults and immature fishes (Figure 3).

\section{Discussion}

The current study is the first to investigate the reproductive biology of a silver John dory virgin stock. As mentioned earlier, prior to the current study, there are few references (Haimovici 

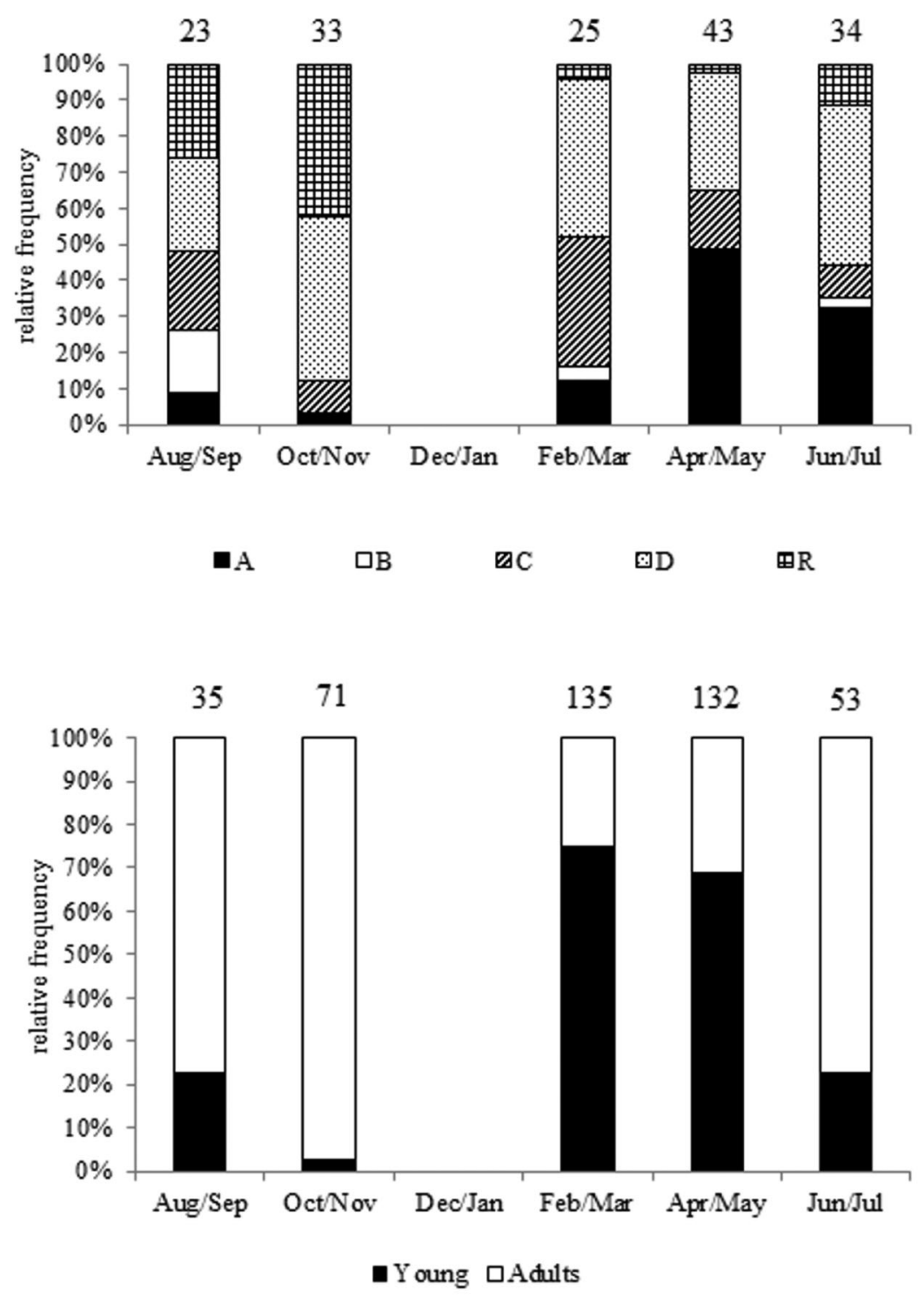

(a)

(b)

Figure 4. Zenopsis conchifer: females (a) and males (b) bimonthly frequency of maturation stages (the numbers above the columns indicate the number of individuals analyzed; for females: A - immature, B - developing, C - spawning capable early development, D - spawning capable actively spwaning, $\mathrm{R}$ - regression/regeneration).

et al., 2008; Vaz-dos-Santos, 2009; Martins and Schwingel, 2012) about the theme, which restricts comparisons.

The results of sex ratio revealed the intrinsic pattern of $Z$. conchifer in the area, which constitutes an essential element for understanding the structure of these schools structure (Walters \& Martell 2004). The higher proportion of females observed in larger length classes is probably due to a differential growth rate, because there was neither evidence of aggregations during the spawning period nor spatial segregation according to length or to stages of maturation as suggested by Vazzoler (1996). Similarly, at the beginning of the 2000s, when harvesting over the species started, specimens caught had lengths of $81-525 \mathrm{~mm}$ Ls and females also predominated in the majority of length classes (Martins \& Schwingel 2012). Parity of sexes occurred at

Table 2. Zenopsis conchifer: Kolmogorov-Smirnov test results for the frequency distribution of fish by period (asterisks indicates significant differences).

\begin{tabular}{llccc}
\hline Sex & Statistics & Aug/Sep vs. Oct/Nov & Feb/Mar vs. Apr/May & Apr/May vs. Jun/Jul \\
\hline \multirow{2}{*}{ Females } & $\chi_{\text {KS }}^{2}$ & 69.114 & 85.809 & 33.489 \\
\multirow{2}{*}{ Males } & P-value & $0.0316^{*}$ & $0.0137^{*}$ & 0.1874 \\
& $\chi^{2}{ }_{\text {KS }}$ & 37.661 & 0.9216 & 324.235 \\
& P-value & 0.1521 & 0.6308 & $<0.0001^{*}$ \\
\hline
\end{tabular}




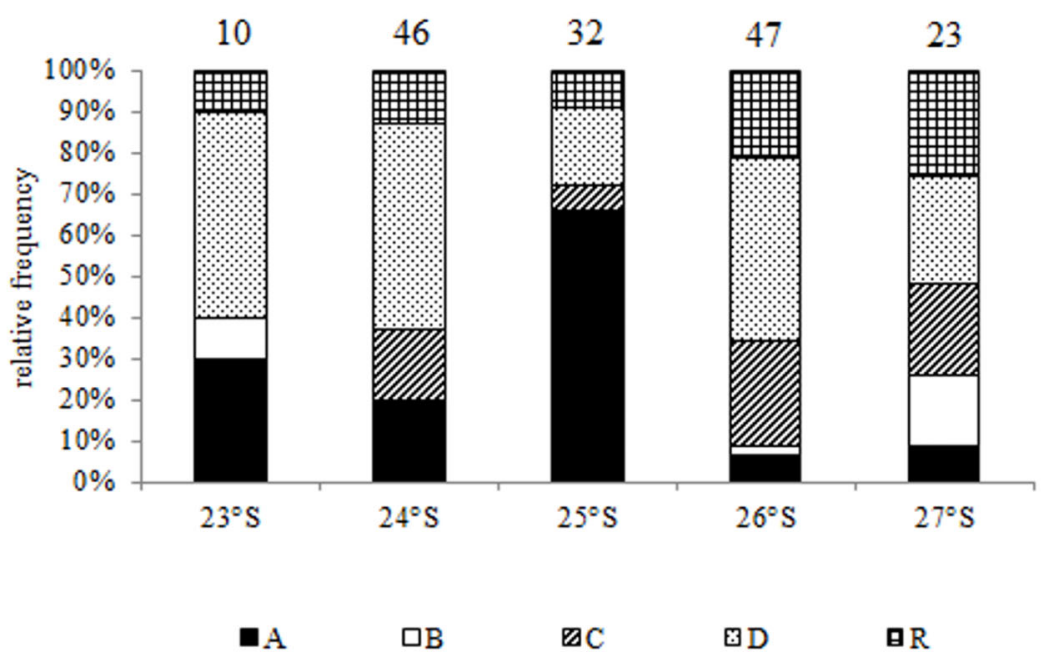

(a)

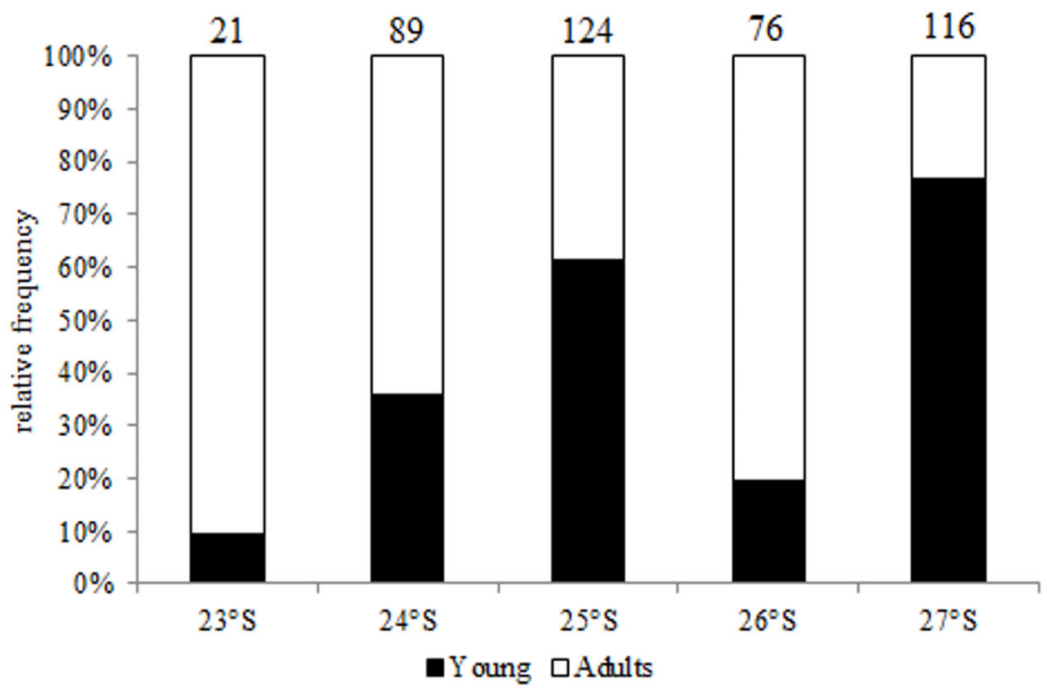

(b)

Figure 5. Zenopsis conchifer: females (a) and males (b) frequency of maturation stages by latitude (the numbers above the columns indicate the number of individuals analyzed; for females: A - immature, B - developing, C - spawning capable early development, D - spawning capable actively spawning, $\mathrm{R}$ - regression/regeneration).

the same length classes both in the virgin stock (present results) and those in the initial exploitation (Martins \& Schwingel, 2012).

The sex ratio and the sex-specific length-frequencies pattern shown by $Z$. conchifer were similar to those of other species that inhabit deep regions of the area surveyed and are targeted by double rigged trawlers (Perez \& Pezzutto 2006). Females of greater length are predominant in Lophius gastrophysus (Lopes
\& Schwingel 2006), Merluccius hubbsi (Vaz-dos-Santos \& Rossi-Wongtschowski 2005, 2007) and Urophycis mystacea (Haimovici et al. 2006). This pattern is known as the biggerdeeper and smaller-shallower paradigm (sensu Macpherson \& Duarte 1991) and Martins \& Schwingel (2012) discussed it. These authors have argued favoring this paradigm (reduction in the competition, food availability and optimization of metabolism) and others adding new elements to explain differential

Table 3. Zenopsis conchifer: Kolmogorov-Smirnov test results for the frequency distribution of fish by area (degree of latitude) (asterisks indicates significant differences).

\begin{tabular}{llcccc}
\hline Sex & Statistics & $\mathbf{2 3}^{\mathbf{0}} \mathbf{S}$ vs. $\mathbf{2 4}^{\mathbf{0}} \mathbf{S}$ & $\mathbf{2 4}^{\mathbf{0}} \mathbf{S}$ vs. $\mathbf{2 5}^{\mathbf{0}} \mathbf{S}$ & $\mathbf{2 5}^{\mathbf{0}} \mathbf{S}$ vs. $\mathbf{2 6}^{\mathbf{0}} \mathbf{S}$ & $\mathbf{2 6}^{\mathbf{0}} \mathbf{S}$ vs. $\mathbf{2 7}^{\mathbf{0}} \mathbf{S}$ \\
\hline Females & $\chi_{\text {KS }}^{2}$ & 13.720 & 160.146 & 267.264 & 19.083 \\
& P-value & 0.50 & $0.0003^{*}$ & $<0.0001^{*}$ & 0.38 \\
\multirow{2}{*}{ Males } & $\chi_{\text {KS }}^{2}$ & 47.480 & 133.028 & 325.447 & 596.467 \\
& P-value & 0.0931 & $0.0013^{*}$ & $<0.0001^{*}$ & $<0.0001^{*}$ \\
\hline
\end{tabular}




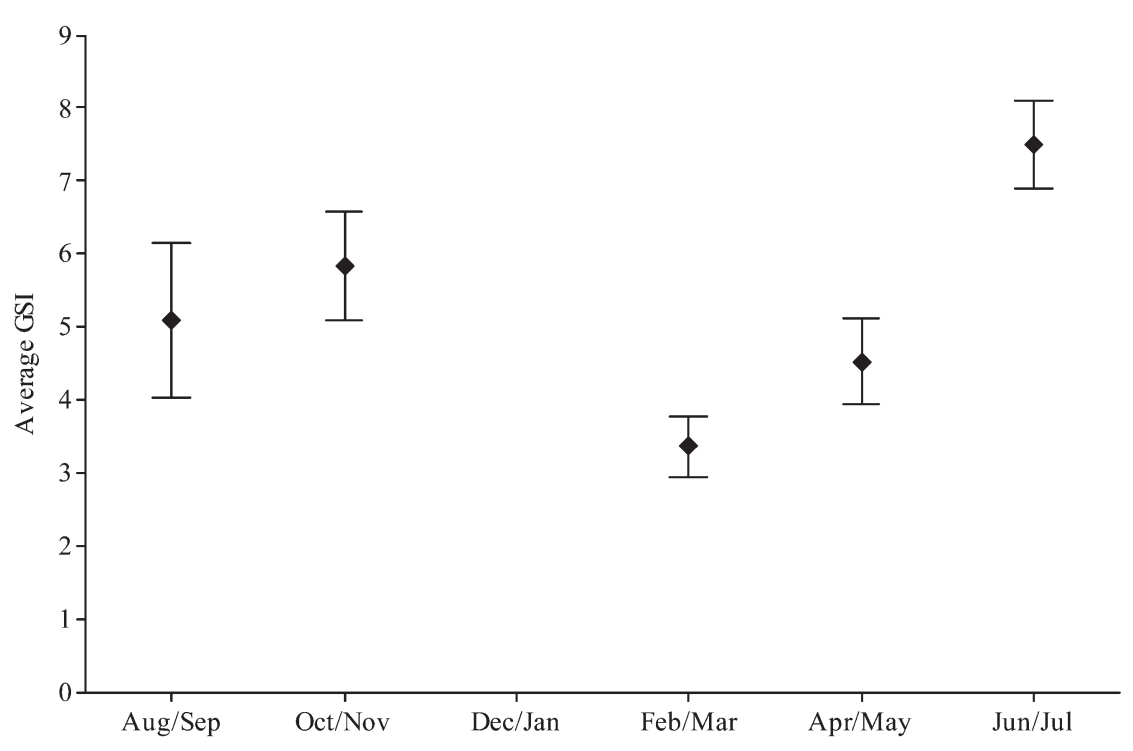

(a)

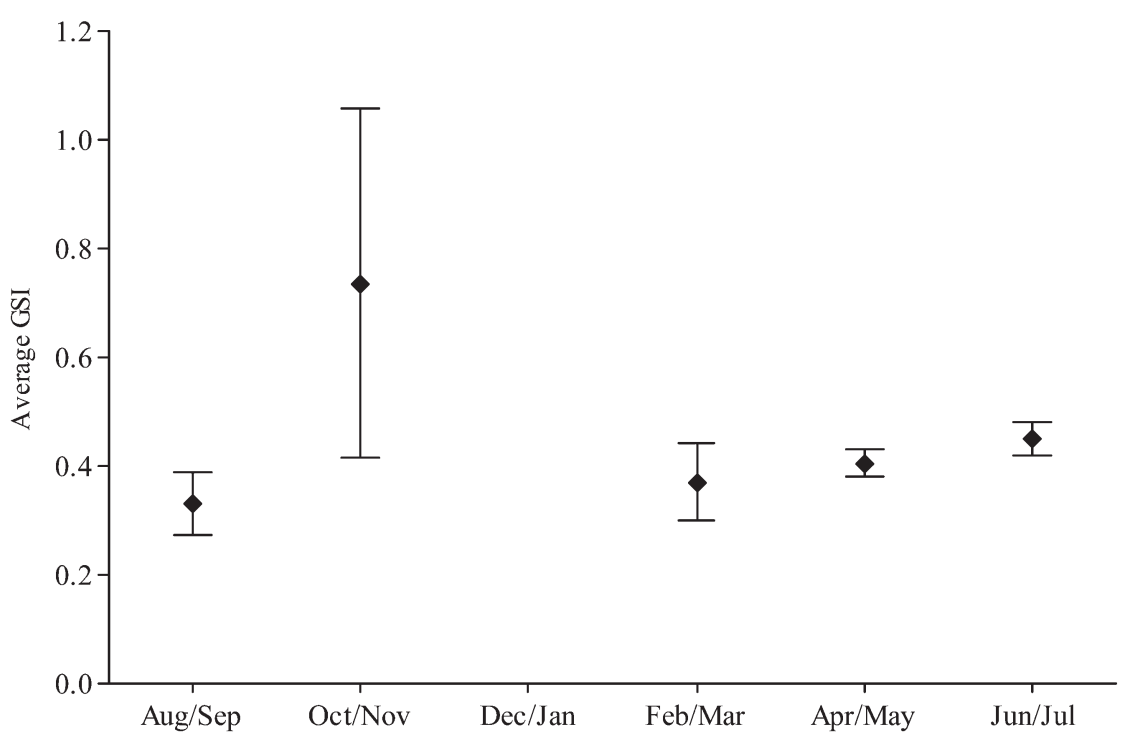

(b)

Figure 6. Zenopsis conchifer: bimonthly average GSI and confidence interval for (a) females $(\mathrm{n}=331)$ and $(\mathrm{b})$ males $(\mathrm{n}=202)$.

distribution (free movements along water column, optimal environmental conditions and restriction of depth due to fishery). Our results reinforce the observations of Martins \& Schwingel (2012), showing large adults of Z. conchifer also occurring at 100-200 m strata of depth.

The length-weight relationships data analysis yielded a value of approximately 2.7 for the allometric coefficient $(b)$. This value reflects the laterally compressed body shape of the silver John dory, a schooling species with a low body volume and a carangid swimming pattern (Pough et al. 2008). Lengthweight relationship values for $Z$. conchifer are available in Haimovici \& Velasco (2000) for southern Brazil $\left(a=1.42 \times 10^{-5}\right.$ and $b=2.9549)$. For southeastern and southern Brazilian waters, Madureira \& Rossi-Wongtschowski (2005) presented estimates for sexes pooled $\left(a=1.17 \times 10^{-4}\right.$ and $\left.b=2.627\right)$ and Martins $\&$ Schwingel (2012) for sexes separated $\left(a=5 \times 10^{-5}\right.$ and $b=2.758$ for females and $a=5 \times 10^{-5}$ and $b=2.696$ for males). These values are consistent with the pattern found by this study in terms of length-weight relative growth.

The silver John dory is a multiple spawner fish (Vaz-dosSantos 2009). The recovery of the gonads (especially the ovaries) led to the long spawning period observed, extending that observed by Martins \& Schwingel (2012). The use of two techniques combined (maturation + GSI) allow to identify the breeding season in multiple spawners (Núñez \& Duponchelle 2009) and the results of females, whose ovaries were staged by histology (Vaz-dos-Santos 2009), were considered more refined than males. Most studies on fish reproduction have been still detailing only females (Núñez \& Duponchelle 2009, LowerreBarbieri et al. 2011) due to their more significant contribution to the recruitment (see Palumbi 2004). In this regard, LowerreBarbieri et al. (2011) call attention to the effects of an extended spawning season that leads to a wide range of hatchings and increases individual and population reproductive success. 
Larger females also ensure better oocytes and then eggs (Palumbi 2004). Our results do not allow to evaluate that, but it seems that these considerations apply to $Z$. conchifer.

Longhurst \& Pauly (2007) cite other species with an extended reproductive cycle, a usual pattern common to species with asynchronous oocyte development and multiple spawning (West 1990, Rocha \& Rocha 2006), such as Z. conchifer. The occurrence of $Z$. conchifer larvae in the oceanic area from October through December (Katsuragawa 2007) supports our findings about the period of relatively intensive spawning of the silver John dory in the area studied. Katsuragawa's (2007) results suggest that the spawning of the species in southern Brazilian waters depends on the intrusion of warm waters, which become more constant in springtime (Castro et al. 2006). Weiss et al. (1987) investigated the larval development of $Z$. conchifer in southern Brazil. They found larvae at water temperatures between $17.5^{\circ} \mathrm{C}$ and $23.4^{\circ} \mathrm{C}$ and salinities between 32.2 and 36.6 (Tropical Water and some mixture of water masses) from July through November on the shelf break and upper slope. The authors of that study suggested that the reproduction of $Z$. conchifer in southern Brazilian waters was related to the warm and saline conditions of the Tropical Water, contrary to the environmental conditions at which the adults inhabits, once that our results showed the silver John dory occurring mainly associated with the cold nutrient-rich waters of the South Atlantic Central Water (SACW).

In relation to spawning period, in the southwestern Atlantic other teleost species living on the shelf break reproduce at the same time as Z. conchifer. Ariomma bondi usually spawn between March and October (Vaz-dos-Santos et al. 2013). Lopholatilus villarii spawns from September to December (Ávila-da-Silva \& Haimovici 2005). Lophius gastrophysus shows a spawning peak between July and October (Lopes \& Schwingel 2006). Urophycis mystacea spawns in July and August (Haimovici et al. 2006). All of the authors quoted above found difficulties to relate spawning to environmental characteristics. However, Cury \& Pauly (2000) remark that periods of better productivity favor egg and larval survival during the austral spring and summer. In this way, the Brazil Currents water flow and the higher intensity of the upwelling during spring and summer could create more favorable conditions for larval survival (Braga \& Niencheski 2006).

The use of a precise scale to staging ovaries (Vaz-dos-Santos 2009) was essential to assess the first maturity (Núñez \& Duponchelle 2009). The first maturity affects generation time, influences the intrinsic rate of population growth, constitutes a biological reference for harvesting and is used to estimate spawning stock biomass (Longhurst \& Pauly 2007, LowerreBarbieri et al. 2011). It occurs when there are metabolic conditions to somatic and reproductive growth, represented by a ratio (from 0.4 to 0.9 ) between the $\mathrm{L}_{50}$ and the $\mathrm{L}_{\infty}$ (Longhurst \& Pauly 2007). Although there is no available information about $Z$. conchifer growth, a gross estimate of $0.44\left(\mathrm{~L}_{50} /\right.$ $\mathrm{Ls}_{\text {maximum }}$ ) follows the general patterns stated by Longhurst \& Pauly (2007), with the lowest values associated to the largest fishes.

The values of first maturity obtained here came from the virgin stock and constitute a referential, but they may change due to harvesting and they must not be used as a statical reference (Lowerre-Barbieri 2009). For example, in the same fishery of $Z$. conchifer this fact occurred with Merluccius hubbsi, whose first maturity suffered an alarming decrease due to overexploitation (Vaz-dos-Santos et al. 2005, 2009). Martins \& Schwingel (2012) estimated the $\mathrm{L}_{50}$ value for females ( $245 \mathrm{~mm}$ Ls corresponding to $311 \mathrm{~mm} \mathrm{Lt}$ ), higher than the value presented. This difference was probably methodological, once authors did not included maturing (similar to our developing stage) in their calculations.

This study provides the first information about the reproductive biology of a virgin stock of the silver John dory. The results of the study show that the species exhibits a strategy similar to that of other teleost fishes in the area. These patterns consist of the occupation of deeper regions by older and larger fish, particularly females, a long period of spawning and the alternation of intense periods of recruitment and spawning. These results must be taken into consideration for evaluating the status of the $Z$. conchifer population and the effects of fisheries on the stock.

\section{Acknowledgments}

The authors express their gratitude to FAPESP for financial support (Process number 2007/00805-8), to an anonymous FAPESP and all journals referees, whose recommendations were invaluable, and to Dr. Maria Inês Borella and Dr. June Ferraz Dias for teaching us and granting us permission to use their equipment.

\section{Literature cited}

ÁVILA-DA-SILVA，A.O. \& HAIMOVICI，M. 2005. Lopholatilus villarii Miranda Ribeiro, 1915. In Análise das principais pescarias comerciais da região Sudeste-Sul do Brasil: dinâmica populacional das espécies em explotação (Cergole, M.C., AVila-Da-Silva., A.O., \& Rossi-Wongtschowski, C.L.D.B. eds.). Instituto OceanográficoUSP/Série Documentos REVIZEE, São Paulo, p.74-80.

BERNARDES, R.A., FIGUEIREDO, J.L., RODRIGUES, A.R., FISCHER, L.G., VOOREN, C.M., HAIMOVICI, M. \& ROSSIWONGTSCHOWSKI, C.L.D.B. 2005. Peixes da Zona Exclusiva da região Sudeste e Sul do Brasil: levantamento com armadilhas pargueiras e rede de arrasto de fundo. Instituto OceanográficoUSP/Série Documentos REVIZEE, São Paulo.

BRAGA, E.S. \& NIENCHESKI, L.F.H. 2006. Composição das massas de água e seus potenciais produtivos na área entre o Cabo de São Tomé (RJ) e o Chuí (RS). In O ambiente oceanográfico da plataforma continental e do talude na região Sudeste-Sul do Brasil (Rossi-Wongtschowski, C.L.D.B., \& Madureira, L.S.P. eds.). EDUSP, São Paulo, p.161-218.

BRASIL. Ministério do Meio Ambiente - MMA. 2006. Programa REVIZEE: avaliação do potencial sustentável de recursos vivos da Zona Econômica Exclusiva do Brasil - relatório executivo. MMA, Brasília.

BROWN-PETERSON, N.J., WYANSKI, D.M., SABORIDO-REY, F., MACEWICZ, B.J. \& LOWERRE-BARBIERI, S.K. 2011. A standardized terminology for describing reproductive development in fishes. Mar. Coast. Fish. 3(1):52-70, http://dx.doi.org/10.1080/ 19425120.2011.555724

CASTRO, B.M., LORENZETTI, J.A., SILVEIRA, I.C.A. \& MIRANDA, L.B. 2006. Estrutura termohalina e circulação na região entre o Cabo de São Tomé (RJ) e o Chuí (RS). In $\mathrm{O}$ ambiente oceanográfico da plataforma continental e do talude na região Sudeste-Sul do Brasil (Rossi-Wongtschowski, C.L.D.B. \& Madureira, L.S.P. eds.). EDUSP, São Paulo, p. 11-120.

CURY, P. \& PAULY, D. 2000. Patterns and propensities in reproduction and growth of marine fishes. Ecol. Res. 15:101-106, http://dx.doi.org/10.1046/j.1440-1703.2000.00321.x

FIGUEIREDO, A.G. \& MADUREIRA, L.S.P. 2004. Topografia, composição, refletividade do substrato marinho e identificação de 
províncias sedimentares na região Sudeste-Sul do Brasil. Instituto Oceanográfico-USP/Série Documentos REVIZEE, São Paulo.

FIGUEIREDO, J.L. \& MENEZES, N.A. 1980. Manual de peixes marinhos do Sudeste do Brasil vol. III: Teleostei (2). Museu de Zoologia da Universidade de São Paulo, São Paulo.

FIGUEIREDO, J.L., SANTOS, A.P., YAMAGUTI, N., BERNARDES, R.A. \& ROSSI-WONGTSCHOWSKI, C.L.D.B. 2002. Peixes da Zona Econômica Exclusiva da região Sudeste-Sul do Brasil: levantamento com rede de meia água. EDUSP, São Paulo.

FOCK, H.O. \& ZIDOWITZ, H. 2004. Episodic recruitment to seamount populations: evidence from Zenopsis conchifer (Lowe, 1852) at the Great Meteor Seamount (Subtropical North-east Atlantic). Arch. Fish. Mar. Res. 51:287-293.

FONTELES-FILHO, A.A. 2011. Oceanografia, biologia e dinâmica populacional de recursos pesqueiros. Expressão Gráfica, Fortaleza.

FROESE, R. \& PAULY, D. 2013. Fishbase: World Wide Web electronic publication. Available from http://www.fishbase.org. Acessed in 20/May/2013.

GAETA, S.A. \& BRANDINI, F.P. 2006. Produção primária do fitoplâncton na região entre o Cabo de São Tomé (RJ) e o Chuí (RS). In $\mathrm{O}$ ambiente oceanográfico da plataforma continental e do talude na região Sudeste-Sul do Brasil (Rossi-Wongtschowski, C.L.D.B. \& Madureira, L.S.P. eds.). EDUSP, São Paulo, p. 219264

GASALLA, M.A., VELASCO, G., ROSSI-WONGSTCHOWSKI, C.L.D.B., HAIMOVICI, M \& MADUREIRA, L.S.P. 2007. Modelo de equilíbrio de biomassas do ecossistema marinho da região Sudeste-Sul do Brasil entre $100-1000 \mathrm{~m}$ de profundidade. Instituto Oceanográfico-USP/Série Documentos REVIZEE, São Paulo.

HAIMOVICI, M. \& VELASCO, G. 2000. Length-weight relationship of marine fishes from Southern Brazil. Fishbyte 23(1):19-23.

HAIMOVICI, M., ÁVILA-DA-SILVA, A.O. \& FISCHER, L.G. 2006. Diagnóstico do estoque e orientações para o ordenamento da pesca de Urophycis mystacea (Ribeiro, 1903). In Análise das principais pescarias comerciais da região Sudeste-Sul do Brasil: dinâmica populacional das espécies em explotação - II (RossiWongtschowski, C.L.D.B., Cergole, M.C \& ÁVila-Da-Silva, A.O eds.). Instituto Oceanográfico-USP/Série Documentos REVIZEE, São Paulo, p.86-94.

HAIMOVICI, M., MARTINS, A.S., FIGUEIREDO, J.L. \& VIEIRA, P.C. 1994. Demersal bony fish of the outer shelf and upper slope of the southern Brazil Subtropical Convergence Ecosystem. Mar. Ecol. Prog. Ser. 108:59-77, http://dx.doi.org/10.3354/meps108059

HAIMOVICI, M., ROSSI-WONGTSCHOWSKI, C.L.D.B., BERNARDES, R.A., FISCHER, L.G., VOOREN, C.M., SANTOS, R.A., RODRIGUES, A.R. \& SANTOS, S. 2008. Prospecção pesqueira de espécies demersais com rede de arrasto de fundo na região Sudeste-Sul do Brasil. Instituto OceanográficoUSP/Série Documentos REVIZEE, São Paulo.

HUXLEY, J.S. 1993. Problems of relative growth, with a new introduction by Frederick B. Churchill and an essay by Richard E. Strauss. The John Hopkins University Press, Baltimore.

KATSURAGAWA, M. 2007. Ictioplâncton na plataforma continental externa e talude superior do sudeste brasileiro. Tese de Livre Docência, Universidade de São Paulo, São Paulo.

KING, M. 2007. Fisheries biology, assessment and management. 2 ed. Blackwell Publishing, Oxford.

KOLLING, J.A., BATISTA, P.A., ÁVILA-DA-SILVA, A.O. \& CARNEIRO, M.H. 2008. A utilização do ambiente marinho e de seus recursos vivos pela frota pesqueira paulista: o ambiente demersal. Sér. Relat. Téc. 32:1-62.

LONGHURST, A.R. \& PAULY, D. 2007. Ecologia dos oceanos tropicais. EDUSP, São Paulo.

LOPES, F.A.R. \& SCHWINGEL, P.R. 2006. Reprodução, idade e crescimento do peixe-sapo Lophius gastrophysus (Ribeiro, 1915) na região Sudeste e Sul do Brasil. CEPSUL DOC 16 SCC CPG 04:1-5.
LOWERRE-BARBIERI, S.K. 2009. Reproduction in relation to conservation and exploitation of marine fishes. Reproductive biology and phylogeny of fishes (agnathans and bony fishes) Vol 9 Part B(Jamieson, B.G.M, ed. )Science Publishers, Enfield, p.371-394.

LOWERRE-BARBIERI, S.K., GANIAS, K., SABORIDO-REY, F., MURUA, H. \& HUNTER, J.R. 2011. Reproductive timing in marine fishes: variability, temporal scales and methods. Mar. Coast. Fish. 3(1):71-91, http://dx.doi.org/10.1080/19425120.2011.556932

MACPHERSON, E. \& DUARTE, C.M. 1991. Bathymetric trends in demersal fish size: is there a general relationship? Mar. Ecol. Prog. Ser. 71:103-112, http://dx.doi.org/10.3354/meps071103

MADUREIRA, L.S.P \& ROSSI-WONGTSCHOWSKI, C.L.D.B. 2005. Prospecção de recursos pesqueiros pelágicos na Zona Econômica Exclusiva da região Sudeste-Sul do Brasil: hidroacústica e biomassas. Instituto Oceanográfico-USP/Série Documentos REVIZEE, São Paulo.

MARTINS, R.S. \& SCHWINGEL, P.R. 2012. Biological aspects of the sailfin dory Zenopsis conchifer (Lowe, 1852) caught by deep-sea trawling fishery off southern Brazil. Braz. J Oceanogr. 60(2):171179, http://dx.doi.org/10.1590/S1679-87592012000200007

MENEZES, N.A., BUCKUP, P.A., FIGUEIREDO, J.L. \& MOURA, R.L. 2003. Catálogo das espécies de peixes marinhos do Brasil. Museu de Zoologia da Universidade de São Paulo, São Paulo.

MPA. Ministério da Pesca eAquicultura. 2011. Boletim estatístico da pesca e aquicultura 2011. Ministério da Pesca e Aquicultura, Brasília.

MOYLE, P.B. \& CECH, J.J. 2004. Fishes: an introduction to ichthyology. 5 ed. Prentice Hall, Upper River Saddle.

MUTO, E.Y, SILVA, M.H.C., VERA, G.R., LEITE, S.S.M., NAVARRO, D.G. \& ROSSI-WONGTSCHOWSKI, C.L.D.B. 2005. Alimentação e relações tróficas de peixes demersais da plataforma continental externa e talude superior da região SudesteSul do Brasil. Instituto Oceanográfico-USP/Série Documentos REVIZEE, São Paulo.

NÚÑEZ, J. \& DUPONCHELLE, F. 2009. Towards a universal scale to assess sexual maturation and related life history traits in oviparous teleost fishes. Fish Physiol. Biochem. 35(1):167-80, http:// dx.doi.org/10.1007/s10695-008-9241-2

PALUMBI, S.R. 2004. Why mothers matter. Nature 430:621-622, http://dx.doi.org/10.1038/430621a

PEREZ, J.A.A. \& PEZZUTO, P.R. 2006. A pesca de arrasto de talude do Sudeste e Sul do Brasil: tendências da frota nacional entre 20012003. Bol. Inst. Pesca 32(2):127-150.

PEREZ, J.A.A. \& WAHRLICH, R. 2005. A bycatch assessment of the gillnet monkfish Lophius gastrophysus fishery off southern Brazil. Fish. Res. 72:81-95, http://dx.doi.org/10.1016/j.fishres.2004.10.011

PEREZ, J.A.A. 2006. Potenciais de rendimento dos alvos da pesca de arrasto de talude do sudeste e sul do Brasil estimados a partir de parâmetros do ciclo de vida. Braz. J. Aquat. Sci. Technol. 10(2):111, http://dx.doi.org/10.14210/bjast.v10n2.p1-11

PEREZ, J.A.A., WAHRLICH, R., PEZZUTTO, P.R., SCHWINGEL, P.R., LOPES, F.R.A. \& RODRIGUES-RIBEIRO, M. 2003. Deepsea fishery off southern Brazil: recent trends of the Brazilian fishing industry. J. Northwest Atl. Fish. Soc. 31:1-18.

PEREZ, J.A.A., PEZZUTO, P.R., WAHRLICH, R. \& SOARES, A.L.S. 2009. Deep water fisheries in Brazil: history, status and perspectives. Lat. Am. J. Aquat. Res. 37(3):513-542, http:// dx.doi.org/10.3856/vol37-issue3-fulltext-18

POUGH, F.H., JANIS, C.M. \& HEISER, J. 2008. A vida dos vertebrados. $4^{\text {a }}$ ed. Atheneu, São Paulo.

QUERO, J.C. 1998. Changes in the Euro-Atlantic fish species composition resulting from fishing and ocean warming. Ital. J. Zool. 65:493-499, http://dx.doi.org/10.1080/11250009809386873

QUINN II, T.J \& DERISO, R.B. 1999. Quantitative fish dynamics. Oxford University Press, New York.

ROCHA, M.J. \& ROCHA, E. 2006. Morphofunctional aspects of reproduction from synchronous to asynchronous fishes - an overview. In: Fish endocrinology (Reinecke, M., Zaccone, G \& Kappor, B.G.eds. ). Science Publishers, New Hampshire, p.570-624. 
SIBENI, F. \& CALDERINI, F. 2012. FishStatJ, a tool for fishery statistics analysis. Release: 2.0.0. http://www.fao.org/fishery/statistics/software/fishstatj/en Accessed in 20/May/2013.

SILVEIRA, I.C.A., SCHMIDT, A.C.K., CAMPOS, E.J.D., GODOI, S.S. \& IKEDA, I. 2000. Corrente do Brasil ao largo da costa leste brasileira. Braz. J Oceanogr. 48:171-183, http://dx.doi.org/10.1590/ S1679-87592000000200008

SOKAL, R.R. \& ROHLF, F.J. 1995. Biometry. 3 ed. W. H. Freeman and Company, New York.

UNIVALI/CTTMar. 2009. Boletim estatístico da pesca industrial de Santa Catarina - Ano 2008: programa de apoio técnico ao desenvolvimento da pesca no Sudeste e Sul do Brasil. UNIVALI, Itajaí.

UNIVALI/CTTMar. 2011. Boletim estatístico da pesca industrial de Santa Catarina - Ano 2010: programa de apoio técnico ao desenvolvimento da pesca no Sudeste e Sul do Brasil. UNIVALI, Itajaí.

VALENTINI, H. \& PEZZUTTO, P.R. 2006. Análise das principais pescarias comerciais da região Sudeste/Sul do Brasil com base na produção controlada do período 1986 - 2004. Instituto Oceanográfico-USP/Série Documentos REVIZEE, São Paulo.

VASKE JR., T \& CASTELLO, J.P. 1998. Conteúdo estomacal da albacora-laje, Thunnus albacares, durante o inverno e primavera no sul do Brasil. Rev. Bras. Biol. 58(4):639-647, http://dx.doi.org/ 10.1590/S0034-71081998000400011

VAZ-DOS-SANTOS, A.M. 2009. Caracterização do desenvolvimento ovariano e da reprodução do peixe galo-de-profundidade Zenopsis conchifera na região Sudeste-Sul do Brasil. Relatório de Pesquisa, Universidade de São Paulo, São Paulo.

VAZ-DOS-SANTOS, A.M. \& ROSSI-WONGTSCHOWSKI, C.L.D.B. 2005. Merluccius hubbsi Marini, 1933. In : Análise das principais pescarias comerciais da região Sudeste-Sul do Brasil: dinâmica populacional das espécies em explotação (Cergole, M.C., AVila-Da-Silva, A.O., Rossi-Wongtschowski, C.L.D.B. \& eds.). Instituto OceanogrÃfico-USP/SÕrie Documentos REVIZEE, SĐo Paulo, p.88-93.

VAZ-DOS-SANTOS, A.M. \& ROSSI-WONGTSCHOWSKI, C.L.D.B. 2007. Age and growth of the Argentine hake Merluccius hubbsi Marini, 1933 in the Brazilian South-Southeast Region during 1996-2001. Neotrop. Ichthyol. 5(3):375-386, http:// dx.doi.org/10.1590/S1679-62252007000300017

VAZ-DOS-SANTOS, A.M., HONJI, R.M., \& ROSSIWONGTSCHOWSKI, C.L.D.B. 2005. Comprimento e idade de primeira maturação gonadal de fêmeas de merluza Merluccius hubbsi Marini, 1933 na região Sudeste-Sul do Brasil. Bol. Inst. Pesca 31(2):109-117.

VAZ-DOS-SANTOS, A.M., ROSSI-WONGTSCHOWSKI, C.L.D.B. \& FIGUEIREDO, J.L. 2009. Parâmetros da reprodução e relação comprimento-peso da merluza Merluccius hubbsi (Teleostei: Merlucciidae), estoque sudeste brasileiro $\left(21^{\circ} \mathrm{S}-29^{\circ} \mathrm{S}\right)$, ano 2004. Bol. Inst. Pesca 35(1):1-16.

VAZ-DOS-SANTOS, A.M., ROSSI-WONGTSCHOWSKI, C.L.D.B., PEREIRA, N.B., KUCHINSKI, F.B. \& FERNANDES, J. 2013. Biologia reprodutiva do rombudo Ariomma bondi (Teleostei: Ariommatidae) na bacia do Sudeste do Brasil. Bol. Inst. Pesca 39(1):27-36.

VAZZOLER, A.E.A. DE, M. 1996. Biologia da reprodução de peixes teleósteos: teoria e prática. EDUEM, Maringá.

VAZZOLER, G. \& IWAI, M. 1971. Relatório sobre prospecção e pesca exploratória na plataforma continental do Rio Grande do Sul. Contrib. Avulsas Inst. Oceanogr. Oceanogr. Biol. 25:1-79, http:// dx.doi.org/10.1590/S0373-55241971000200001

VINCENT, A. \& SADOVY, A. 1998. Reproductive ecology in the management and conservation of fishes. In :Behavioral Behavioral ecology and conservation biology (Caro, T.M ed.). Oxford Univsertiy Press, New York, p.209-245.

WALTERS, C.J. \& MARTELL, S.J.D. 2004. Fisheries ecology and management. Princeton University Press, Princeton.

WEISS, G., HUBOLD, G \& BAINY, A.C.D. 1987. Larval development of the Zeiform fishes Antigonia capros Lowe, 1843 and Zenopsis conchifer (Lowe, 1852) from the South West Atlantic. Cybium 11(1):79-91.

WEST, G. 1990. Methods of assessing ovarian development in fishes: a review. Aust. J. Mar. Fresh. Res. 41:199-222, http://dx.doi.org/ 10.1071/MF9900199

WOOTTON, R.J. 1998. Ecology of teleost fishes. 2 ed. Chapman and Hall, London.

YESAKI, M., RAHN, E. \& SILVA, G. 1976. Sumário das explorações de peixes de arrasto de fundo ao largo da costa Sul do Brasil. Ser. Doc. Tec. / Inst. Pesqui. Desenvolv. Pesq. 19:1-37.

ZAR, J.H. 2010. Biostatistical analysis. 5 ed. Prentice Hall, New Jersey.

ZIDOWITZ, H. \& FOCK, H.O. 2004. Trophic ecology of Zenopsis conchifer (Lowe, 1852) at the Great Meteor Seamount (subtropical North-east Atlantic). Arch. Fish. Mar. Res. 51: 279-286. 